\title{
DOSIS PASIEN PADA PEMERIKSAAN RUTIN SINAR-X RADIOLOGI DIAGNOSTIK
}

\section{Eri Hiswara, Dewi Kartikasari}

\author{
Pusat Teknologi Keselamatan dan Metrologi Radiasi BATAN \\ Jalan Lebak Bulus Raya No. 49, Jakarta Selatan \\ E-mail: e.hiswara@batan.go.id
}

Diterima: 03-02-2015

Diterima dalam bentuk revisi: 27-05-2015

Disetujui: 15-07-2015

\begin{abstract}
ABSTRAK
DOSIS PASIEN PADA PEMERIKSAAN RUTIN SINAR-X RADIOLOGI DIAGNOSTIK. Teknik diagnosis untuk melihat kondisi fisik seorang pasien dengan menggunakan pesawat sinar-X merupakan teknik yang paling banyak digunakan di dunia. Berdasarkan Badan PBB untuk Efek Radiasi Atom (UNSCEAR), pajanan radiasi sinar-X pada pemeriksaan rutin radiologi diagnostik memberikan kontribusi terbesar bagi penerimaan dosis radiasi oleh penduduk dunia. Untuk kepentingan keselamatan pasien, Badan Tenaga Atom Internasional (IAEA) telah merekomendasikan penggunaan tingkat acuan diagnostik (DRL) agar dosis radiasi yang diterima pasien tersebut optimum sambil tetap mempertahankan kualitas citra film yang dihasilkan dari aplikasi ini. Dalam kaitan ini telah dilakukan studi tingkat dosis radiasi yang diterima oleh pasien dari aplikasi radiasi di bidang radiologi diagnostik. Hasil studi dibandingkan dengan tingkat acuan diagnostik yang berlaku di Indonesia. Studi dilakukan dengan melakukan pengukuran dosis permukaan masuk pada 130 orang pasien yang menjalani pemeriksaan thorax (AP/PA), thorax lat, abdomen, kepala AP/PA, kepala Lat, lumbo sacral AP, lumbo sacral Lat, ekstremitas, pelvis AP, cervical AP, cervical Lat, cervical oblique, clavicula dan thoracal lumbal di tiga rumah sakit di kota Makassar, Sukabumi, dan Pontianak. Hasil studi menunjukkan bahwa data dosis radiasi yang diterima pasien pada pemeriksaan thorax AP/PA, thorax lat, abdomen, kepala AP/PA, kepala lat, lumbosacral AP, lumbosacral lat dan pelvis AP menunjukkan nilai yang tidak melebihi nilai tingkat acuan diagnostik yang berlaku di Indonesia, dan dosis radiasi yang diterima pasien anak lebih rendah daripada dosis pasien dewasa. Perbandingan nilai dosis pasien yang diperoleh pada studi ini dan di Malaysia dengan hasil yang diperoleh dari beberapa negara maju juga memperlihatkan bahwa dosis pasien di negara berkembang relatif tidak berbeda dengan dosis pasien di negara-negara maju tersebut.
\end{abstract}

Kata kunci: pesawat sinar- $\mathrm{X}$, dosis permukaan masuk, radiologi diagnostik, tingkat acuan diagnostik

\section{ABSTRACT}

DOSES TO PATIENTS IN ROUTINE X-RAY EXAMINATIONS OF DIAGNOSTIC RADIOLOGY. Diagnostic technique to study physical condition of a patient using $X$-rays is the most common technique used in the world. According to the United Nations Scientific Committee on Effects of Atomic Radiation (UNSCEAR), radiation exposures in routine X-rays examination of diagnostic radiology contribute to the biggest portion of radiation doses received by world's population. For the purposes of patient safety, diagnostic reference levels have been recommended by the International Atomic Energy Agency (IAEA) to be used in order to optimize the dose received by patient while maintaining quality of film image produced by these procedures. In this regard study on the determination of the level of radiation doses received by patient, has been carried out. Results of study are compared to the diagnostic reference levels for medical exposures applied in Indonesia. The study was performed by measuring entrance surface doses in 130 patients who underwent the X-ray examinations of thorax AP/PA, thorax lat, abdomen, skull AP/PA, skull Lat, lumbo sacral AP, lumbo sacral Lat, extremities, pelvis AP, cervical AP, cervical Lat, cervical oblique, clavicula and thoracal lumbal in three hospitals in the cities of Makassar, Sukabumi, dan Pontianak. The results show all data of patient doses from examinations of thorax AP/PA, thorax lat, abdomen, skull AP/PA, skull Lat, lumbo sacral AP, 
lumbo sacral Lat, extremities and pelvis APwere less than the levels applied in Indonesia and doses received by children were less than those by adult patients. Comparison of data obtained in this study and in Malaysia as developing countries with those from advanced countries also showed that they were relatively no difference between the two groups.

Keywords: X-ray machine, entrance surface doses, diagnostic radiology, diagnostic reference level

\section{PENDAHULUAN}

Aplikasi radiasi di bidang medik merupakan sumber pajanan publik buatan yang terbesar yang diterima oleh penduduk dunia. Komite IImiah PBB untuk Efek Radiasi Atom (UNSCEAR) menyatakan bahwa bagian terbesar dari aplikasi radiasi di bidang medik ini adalah dari pajanan radiasi sinar-X pada pemeriksaan rutin radiologi diagnostik (1).

Pada tahun 2000 jumlah pemeriksaan rutin sinar- $X$ radiologi diagnostik yang dilakukan di seluruh dunia dilaporkan sekitar 1910 juta, dengan dosis efektif kolektif dan dosis per kapita sebesar masing-masing 2,3 juta man - Sv dan 0,4 mSv. Pada tahun 2008, jumlah pemeriksaan meningkat menjadi 3100 juta, dengan dosis efektif kolektif menjadi 4 juta man - Sv dan dosis per kapita $0,6 \mathrm{mSv}$ (1). Dari kedua data terlihat bahwa dalam kurun waktu delapan tahun telah terjadi peningkatan jumlah pemeriksaan lebih dari $60 \%$, yang diikuti dengan peningkatan dosis efektif kolektif sebesar $74 \%$ dosis per kapita sebesar $50 \%$.

Mengingat tingginya kontribusi pemeriksaan rutin sinar- $X$ radiologi diagnostik ini, berbagai negara telah melakukan studi tentang dosis radiasi yang diterima pasien pada radiologi diagnostik. Studi awal telah dilakukan di Inggris oleh National Radiological Protection Board (NRPB) pada tahun 1990 (2). Sejak itu, berbagai negara telah melakukan studi tentang dosis radiasi yang diterima oleh pasien ini, termasuk yang dilakukan Malaysia (3), Mesir (4), Italia (5) negara-negara di Amerika Latin (6), Ghana (7) dan Swiss (8). IAEA juga telah melakukan survei yang sama pada 12 negara di Asia, Afrika dan Eropa Timur (9).

Sebelumnya, di Indonesia telah dilakukan estimasi dosis pasien pada pemeriksaan mammografi (10). Dari studi ini diketahui bahwa nilai rata-rata estimasi MGD (mean glandular dose) yang diterima pasien saat melakukan mammografi adalah $1,460 \mathrm{mGy}$.

Penentuan dosis organ thymus dan tiroid pada pasien foto thorax secara perhitungan juga telah pernah dilakukan di Indonesia (11). Hasil studi menunjukkan bahwa dosis organ thymus rata-rata terhitung adalah sekitar 0,005 - 0,094 mGy, sementara untuk tiroid berkisar antara 0,009 - 0,104 mGy.

Pemeriksaan sinar- $X$ diagnostik pada dasarnya dilakukan untuk memperoleh citra obyek tubuh yang diperiksa. Kecanggihan teknologi citra pada saat ini membawa dampak meningkatnya potensi penerimaan dosis radiasi oleh pasien. Untuk mengendalikan penerimaan dosis pasien ini Badan Pengawas Tenaga Nuklir (BAPETEN) telah memberlakukan nilai tingkat acuan diagnostik (DRL, diagnostic reference level) 
yang diberikan tidak hanya untuk radiografi diagnostik, namun juga untuk CT, mamografi dan fluoroskopi, melalui Keputusan Kepala BAPETEN No. 01-P/Ka-BAPETEN/L03 tentang Pedoman Dosis Pasien Radiodiagnostik.

DRL pada dasarnya merupakan bagian dari proses optimisasi proteksi bagi pasien pada radiologi diagnostik. DRL didefinisikan sebagai nilai kuartil ketiga dari distribusi dosis yang terekam pada satu jenis pemeriksaan yang dilakukan dengan suatu pesawat sinar- $X$ tertentu, yang berarti $75 \%$ dari bacaan terukur berada di bawah nilai tersebut (12). Pada kedokteran nuklir, nilai DRL merupakan jumlah radiofarmaka dalam aktivitas radionuklida yang diberikan kepada pasien (13). Jika perbandingan dengan DRL yang ditetapkan menunjukkan bahwa dosis radiasi atau aktivitas radionuklida lebih besar atau lebih kecil, suatu kajian perlu dilakukan untuk memastikan apakah tindakan proteksi dan keselamatan telah dioptimisasikan dan apakah tindakan perbaikan perlu dilakukan (12)

Pemenuhan nilai DRL juga berkaitan dengan kualitas citra yang diperlukan untuk memberikan kepercayaan pada hasil diagnostik yang diperoleh (12). Jika dosis radiasi yang diterima pasien masih dalam batas $D R L$, citra yang dihasilkan oleh pesawat sinar-X yang digunakan umumnya juga telah memiliki kualitas yang baik.

Mengingat kondisi fisik setiap orang di Indonesia tidak sama dengan kondisi fisik orang di negara dimana nilai DRL ditetapkan, maka nilai DRL yang diberikan oleh BAPETEN tersebut belum tentu sesuai dengan kondisi Indonesia. Untuk itu
Indonesia juga diharapkan dapat memiliki data mengenai dosis yang diterima oleh pasien yang menjalani pemeriksaan medik yang kemudian dapat digunakan untuk menentukan nilai DRL Indonesia.

Dalam penelitian telah dilakukan studi tentang dosis radiasi yang diterima pasien yang menjalani pemeriksaan radiologi diagnostik dengan pesawat sinar-X. Tujuan studi adalah untuk memperoleh gambaran mengenai jumlah dosis radiasi yang diterima pasien radiologi diagnostik di Indonesia pada berbagai jenis pemeriksaan. Hasil kajian dosis radiasi yang diterima pada studi ini selanjutnya akan dikembangkan dan diperluas untuk digunakan dalam menentukan DRL yang berlaku untuk kondisi Indonesia.

\section{TATA KERJA}

Penentuan tingkat penerimaan dosis pasien dilakukan dengan menggunakan dosimeter termoluminesensi (TLD) Thermo Scientific Harhaw dari jenis chip TLD-100 (LiF:Mg,Ti) dengan ukuran 3,2 mm x 3,2 mm x 0,15 mm. Chip TLD di-anneal pada suhu $400^{\circ} \mathrm{C}$ selama satu jam, kemudian pada suhu $80^{\circ} \mathrm{C}$ selama $20 \mathrm{jam}$. TLD yang telah disinari dibaca dengan TLD reader Harshaw model 3500 .

Kalibrasi TLD dilakukan di Fasilitas Kalibrasi PTKMR BATAN. Semua TLD disinari dengan prosedur yang sama, yaitu disinari dengan sumber radiasi sinar- $\mathrm{X} 70$ $k V p$ pada jarak $50 \mathrm{~cm}$ dan lapangan $10 \mathrm{~cm} x$ $10 \mathrm{~cm}$. Hanya TLD dengan simpangan baku $\pm 5 \%$ yang digunakan dalam penelitian ini.

Pengukuran dosis pasien yang menjalani pemeriksaan rutin sinar - $\mathrm{X}$ radiologi 
diagnostik dilakukan dengan protokol yang dikembangkan pertama kali oleh IAEA (14). Pengukuran dosis pasien dilakukan dengan menempelkan TLD chip langsung di tubuh pasien tersebut, sehingga dosis yang terukur disebut pula sebagai dosis permukaan masuk (ESD, Entrance Surface Dose). Gambar 1 memperlihatkan konfigurasi pengukuran dosis permukaan masuk ini.

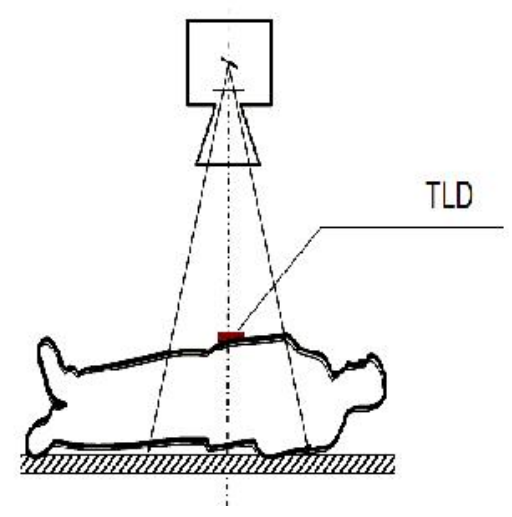

Gambar 1. Konfigurasi pengukuran dosis permukaan masuk.

ESD pada dasarnya adalah dosis serap radiasi yang diterima oleh permukaan tubuh pasien, yang secara sederhana ditentukan sebagai:

$$
\mathrm{ESD}=\text { bacaan TLD } \times \mathrm{FK}
$$

dengan bacaan TLD adalah hasil bacaan TLD dalam $\mathrm{nC}$, dan FK adalah faktor kalibrasi yang diberikan dalam mGy/nC.

Rumah sakit yang dipilih adalah RSU, RSUD atau rumah sakit swasta yang menjadi rujukan di wilayah masing - masing dan memiliki peralatan radiodiagnostik yang lengkap. Berdasar pertimbangan tersebut, penelitian dalam pengukuran dosis pasien radiodiagnostik ini dilakukan di RSUD Dr. Wahidin Sudirohusodo, Makassar, RSUD
Syamsudin, SH, Sukabumi, dan di RS St. Antonius, Pontianak. Pengukuran dosis dilakukan pada sebanyak 130 pasien yang menjalani pemeriksaan thorax (AP/PA), thorax Lat, abdomen, kepala AP/PA, kepala Lat, lumbo sacral AP, lumbo sacral Lat, ekstremitas, pelvis $A P$, cervical AP, cervical Lat, cervical oblique, clavicula dan thoracal lumbal. Hasil penentuan dosis pada semua pasien untuk satu jenis pemeriksaan kemudian dibandingkan dengan nilai DRL yang direkomendasikan oleh IAEA dan diadopsi oleh BAPETEN.

Pasien yang penerimaan dosis radiasinya diukur dibedakan atas pasien dewasa dan pasien anak-anak. Usia pasien anak-anak dibatasi hingga 16 tahun, mengikuti pembahasan pada UNSCEAR yang menyatakan bahwa sebagian besar studi tentang dosis radiasi pada anak-anak dibatasi hingga usia 16 tahun.

\section{HASIL DAN PEMBAHASAN}

Kalibrasi terhadap TLD menghasilkan faktor kalibrasi FK rata - rata sebesar $0,0847 \mathrm{mGy} / \mathrm{nC}$ untuk pengukuran di Makassar, 0,0933 mGy/nC untuk pengukuran di Sukabumi, dan 0,0788 $\mathrm{mGy} / \mathrm{nC}$ untuk pengukuran di Pontianak, masing-masing dengan simpangan baku 4,3\%, 3,9\% dan $3,5 \%$, atau secara keseluruhan $\leq 5 \%$.Nilai faktor kalibrasi ini selanjutnya digunakan untuk menentukan ESD pada masing masing rumah sakit di kota - kota tersebut

Dois permukaan masuk diukur pada sebanyak 130 orang pasien, terdiri atas 102 orang pasien dewasa dan 28 orang pasien anak-anak dengan usia di bawah 16 tahun. Hasil pengukuran dosis permukaan pada 
pemeriksaan thorax (AP, PA), thorax (Lat), abdomen, skull atau kepala (AP/PA), kepala (Lat), lumbo sacral (AP), lumbo sacral (Lat), pelvis (AP), ekstremitas, cervical (AP), dan cervical (Lat) untuk 102 orang pasien dewasa diberikan masing - masing pada Gambar 2 hingga Gambar 12.

Gambar 2 memperlihatkan bahwa dosis rata-rata yang diterima pasien dewasa untuk pemeriksaan thorax AP/PA adalah 0,39 mGy, dengan dosis tertinggi sebesar 2,37 $\mathrm{mGy}$, dosis terendah $0,07 \mathrm{mGy}$ dan dosis median sebesar 0,23 mGy. Bila dibandingkan dengan nilai rekomendasi DRL dari BAPETEN sebesar 0,4 mGy, nilai dosis yang diterima oleh pasien dewasa yang menjalani pemeriksaan thorax AP/PA di tiga rumah sakit tampak relatif sama dengan nilai rekomendasi.

Gambar 3 memperlihatkan bahwa dosis rata-rata yang diterima pasien dewasa untuk pemeriksaan thorax Lat adalah 0,44 mGy, dengan dosis tertinggi sebesar 0,58 mGy, dosis terendah 0,08 $\mathrm{mGy}$ dan dosis median sebesar 0,58 mGy. Bila dibandingkan dengan nilai rekomendasi DRL dari BAPETEN sebesar $20 \mathrm{mGy}$, nilai dosis yang diterima oleh pasien dewasa yang menjalani pemeriksaan thorax Lat di tiga rumah sakit tampak jauh lebih kecil dari nilai rekomendasi.

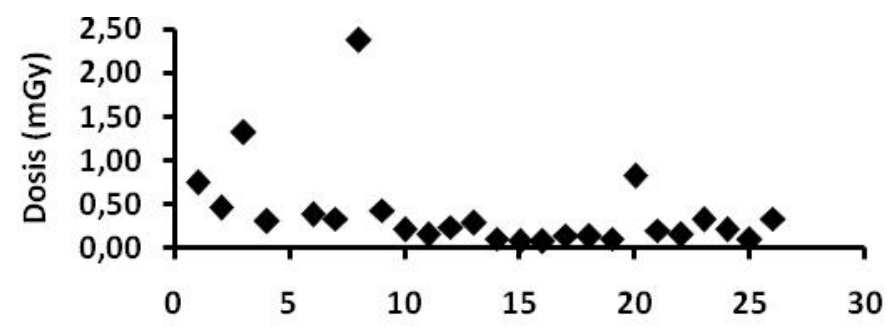

Jumlah Pemeriksaan

Gambar 2. Dosis radiasi yang diterima pasien dewasa pada pemeriksaan thorax AP/PA.

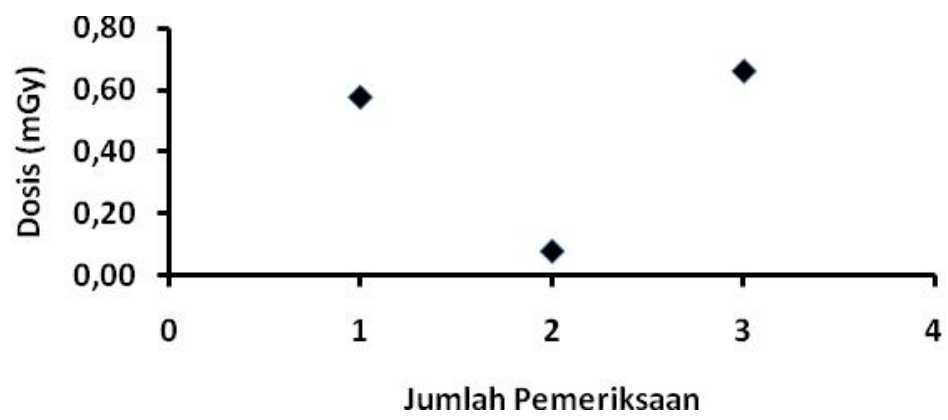

Gambar 3. Dosis radiasi yang diterima pasien dewasa pada pemeriksaan thorax lat.

Gambar 4 memperlihatkan bahwa dosis rata-rata yang diterima pasien dewasa 
untuk pemeriksaan abdomen adalah 1,74 mGy, dengan dosis tertinggi sebesar 3,57 $\mathrm{mGy}$, dosis terendah $0,80 \mathrm{mGy}$ dan dosis median sebesar $1,47 \mathrm{mGy}$. Bila dibandingkan dengan nilai rekomendasi DRL dari BAPETEN sebesar $10 \mathrm{mGy}$, nilai dosis yang diterima oleh pasien dewasa yang menjalani pemeriksaan abdomen di tiga rumah sakit tampak jauh lebih kecil dari nilai rekomendasi.

Gambar 5 memperlihatkan bahwa dosis rata-rata yang diterima pasien dewasa untuk pemeriksaan kepala AP/PA adalah $0,97 \mathrm{mGy}$, dengan dosis tertinggi sebesar $1,06 \mathrm{mGy}$, dosis terendah $0,89 \mathrm{mGy}$ dan dosis median sebesar 0,95 mGy. Bila dibandingkan dengan nilai rekomendasi DRL dari BAPETEN sebesar $5 \mathrm{mGy}$, nilai dosis yang diterima oleh pasien dewasa yang menjalani pemeriksaan kepala AP/PA di tiga rumah sakit tampak jauh lebih kecil dari nilai rekomendasi.

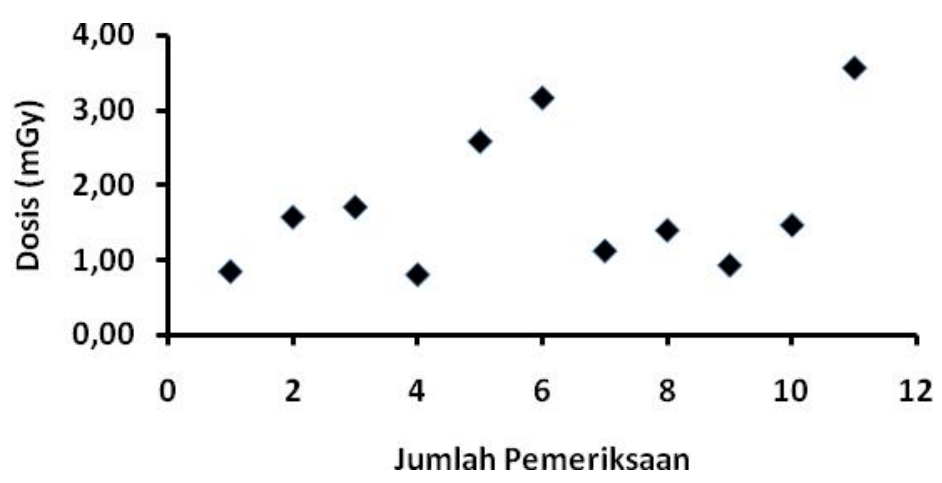

Gambar 4. Dosis radiasi yang diterima pasien dewasa pada pemeriksaan abdomen.

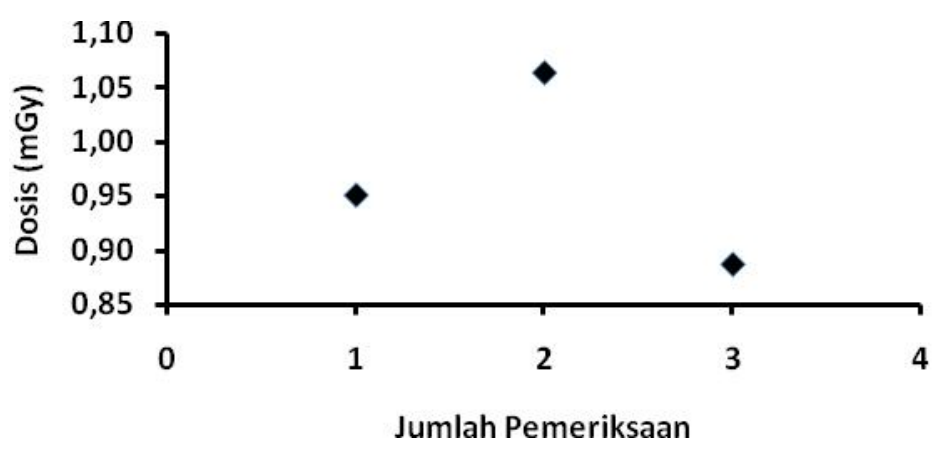

Gambar 5. Dosis radiasi yang diterima pasien dewasa pada pemeriksaan kepala AP/PA. 


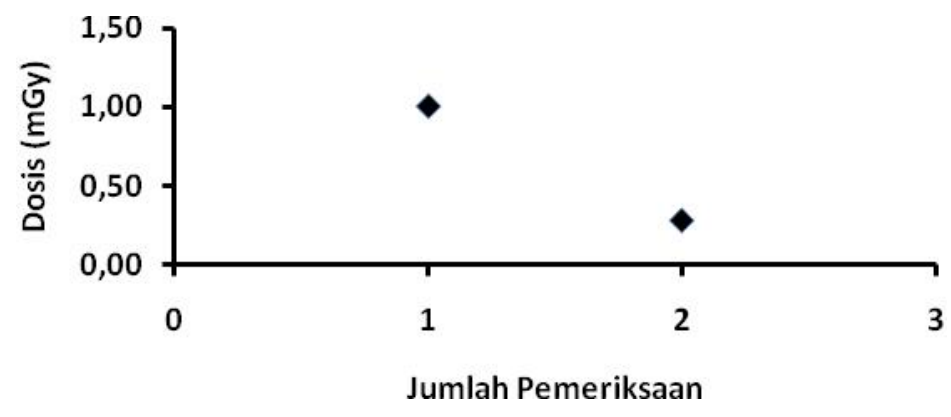

Gambar 6. Dosis radiasi yang diterima pasien dewasa pada pemeriksaan kepala Lat.

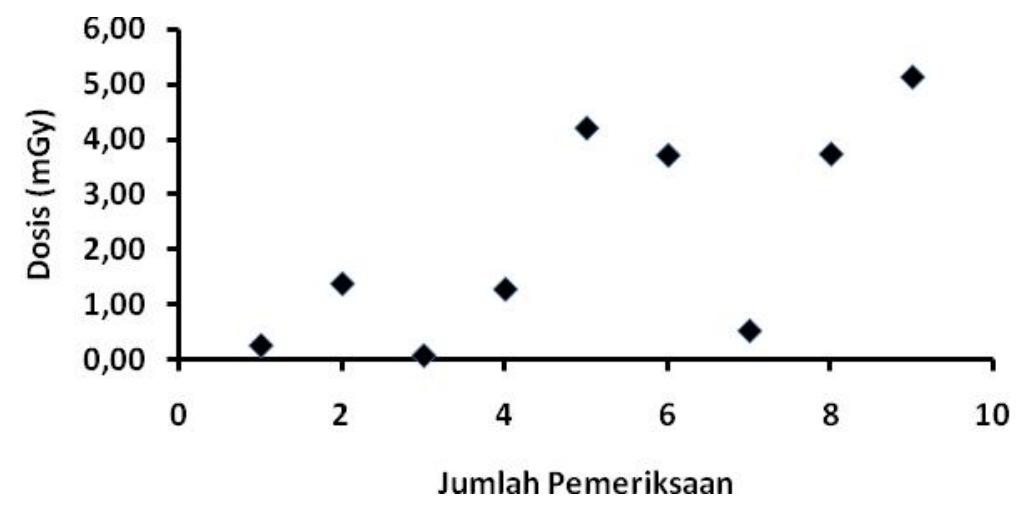

Gambar 7. Dosis radiasi yang diterima pasien dewasa pada pemeriksaan lumbosacral AP.

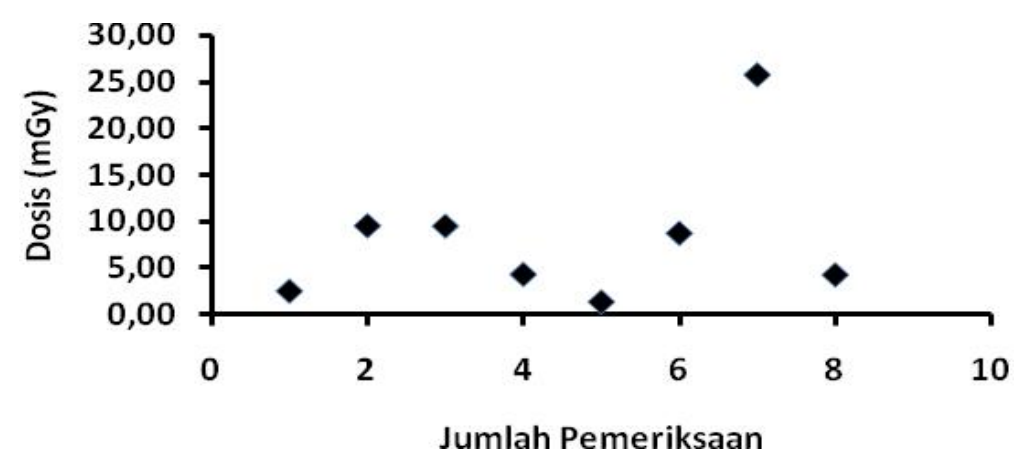

Gambar 8. Dosis radiasi yang diterima pasien dewasa pada pemeriksaan lumbosacral Lat.

Gambar 6 memperlihatkan bahwa dosis rata-rata yang diterima pasien dewasa untuk pemeriksaan kepala Lat adalah 0,64 mGy, dengan dosis tertinggi sebesar 1,00 $\mathrm{mGy}$, dosis terendah 0,28 mGy dan dosis median sebesar 0,64 mGy. Bila dibandingkan dengan nilai rekomendasi DRL dari
BAPETEN sebesar $3 \mathrm{mGy}$, nilai dosis yang diterima oleh pasien dewasa yang menjalani pemeriksaan kepala Lat di tiga rumah sakit tampak jauh lebih kecil dari nilai rekomendasi.

Gambar 7 memperlihatkan bahwa dosis rata-rata yang diterima pasien dewasa 
untuk pemeriksaan lumbosacral AP adalah 2,25 mGy, dengan dosis tertinggi sebesar 5,12 mGy, dosis terendah 0,08 mGy dan dosis median sebesar $1,38 \mathrm{mGy}$. Bila dibandingkan dengan nilai rekomendasi DRL dari BAPETEN sebesar $10 \mathrm{mGy}$, nilai dosis yang diterima oleh pasien dewasa yang menjalani pemeriksaan lumbosacral AP di tiga rumah sakit tampak jauh lebih kecil dari nilai rekomendasi.

Gambar 8 memperlihatkan bahwa dosis rata-rata yang diterima pasien dewasa untuk pemeriksaan lumbosacral Lat adalah $8,22 \mathrm{mGy}$, dengan dosis tertinggi sebesar 25,72 mGy, dosis terendah 1,33 mGy dan dosis median sebesar 6,50 mGy. Bila dibandingkan dengan nilai rekomendasi DRL dari BAPETEN sebesar $30 \mathrm{mGy}$, nilai dosis yang diterima oleh pasien dewasa yang menjalani pemeriksaan lumbosacral Lat di tiga rumah sakit tampak jauh lebih kecil dari nilai rekomendasi

Gambar 9 memperlihatkan bahwa dosis rata-rata yang diterima pasien dewasa untuk pemeriksaan pelvis AP adalah 1,37 $\mathrm{mGy}$, dengan dosis tertinggi sebesar 1,40 $\mathrm{mGy}$, dosis terendah $1,35 \mathrm{mGy}$ dan dosis median sebesar 1,37 mGy. Bila dibandingkan dengan nilai rekomendasi DRL dari BAPETEN sebesar $10 \mathrm{mGy}$, nilai dosis yang diterima oleh pasien dewasa yang menjalani pemeriksaan lumbosacral Lat di tiga rumah sakit tampak jauh lebih kecil dari nilai rekomendasi.

Untuk tiga jenis pemeriksaan yang lain, yaitu ekstremitas, cervical AP dan cervical Lat, BAPETEN tidak memberikan nilai DRL-nya. Karena itu, dosis pasien untuk ketiga jenis pemeriksaan ini tidak dapat dibandingkan dengan suatu nilai rekomendasi. Namun demikian, nilai hasil penelitian ini bisa digunakan untuk menentukan DRL Indonesia untuk ketiga jenis pemeriksaan tersebut.

Gambar 10 memperlihatkan penerimaan dosis pasien dewasa untuk pemeriksaan ekstremitas. Gambar tersebut menunjukkan bahwa dosis rata-rata yang diterima pasien dewasa untuk pemeriksaan ekstremitas adalah $0,39 \mathrm{mGy}$, dengan dosis tertinggi sebesar 1,94 mGy, dosis terendah 0,04 $\mathrm{mGy}$ dan dosis median sebesar 0,14 mGy.

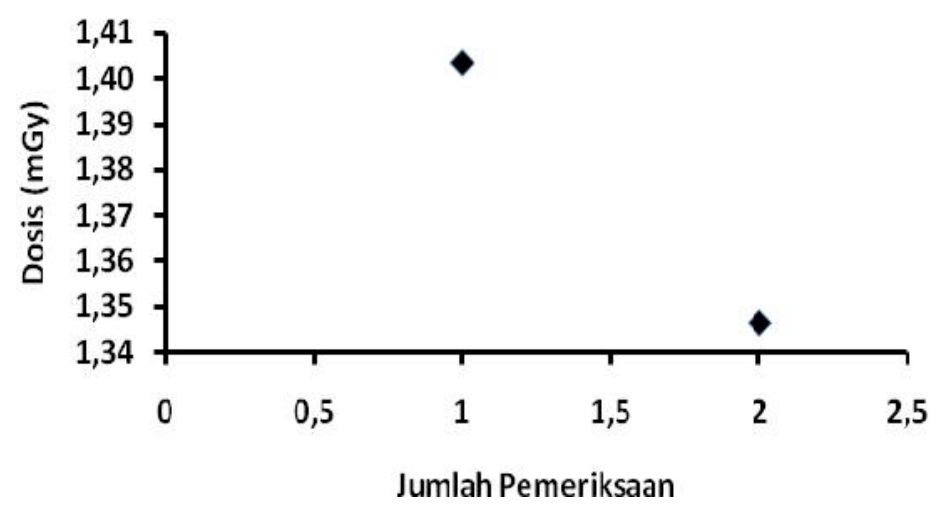

Gambar 9. Dosis radiasi yang diterima pasien dewasa pada pemeriksaan pelvis AP. 


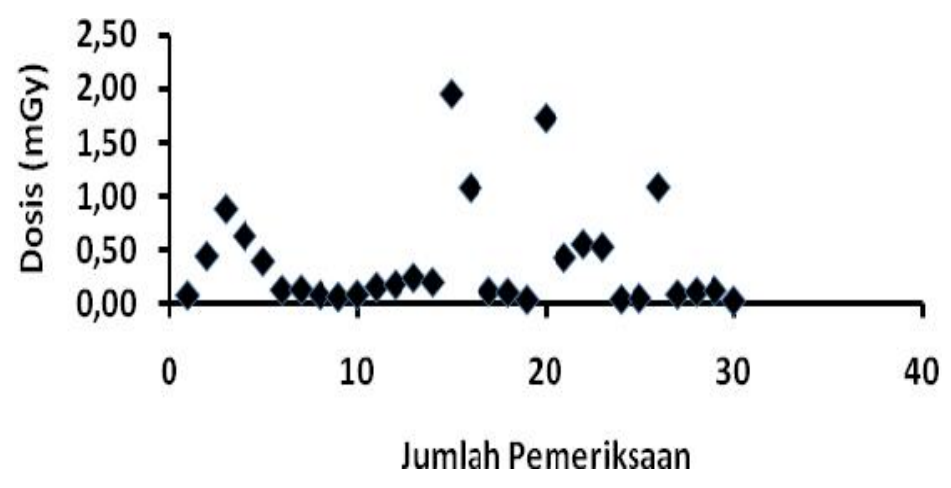

Gambar 10. Dosis radiasi yang diterima pasien dewasa pada pemeriksaan ekstremitas.

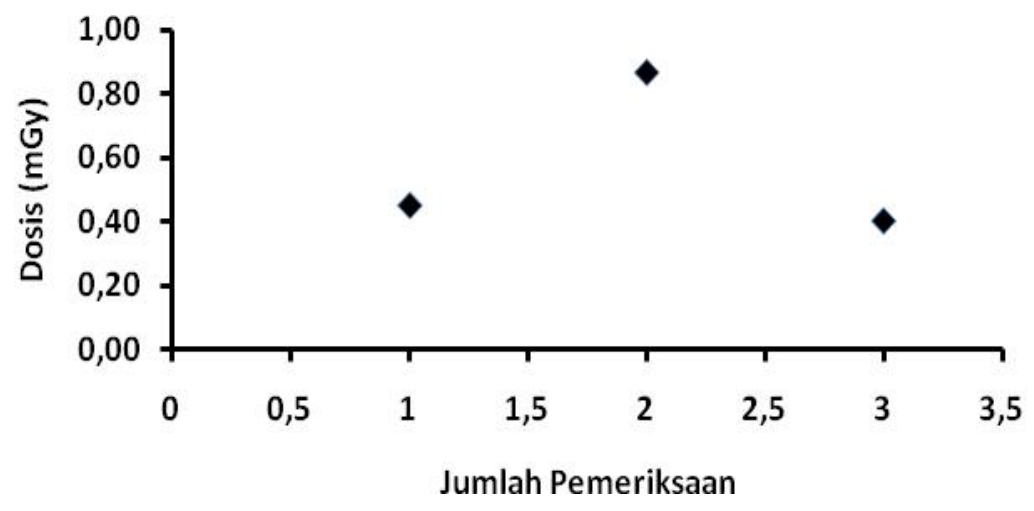

Gambar 11. Dosis radiasi yang diterima pasien dewasa pada pemeriksaan cervical AP.

Untuk pemeriksaan cervical AP, bahwa dosis rata-rata yang diterima pasien Gambar 11 memperlihatkan dosis yang dewasa untuk pemeriksaan cervical Lat diterima oleh pasien dewasa dalam adalah 0,99 $\mathrm{mGy}$, dengan dosis tertinggi penelitian ini. Gambar tersebut menunjukkan sebesar 1,75 mGy, dosis terendah 0,24 bahwa dosis rata-rata yang diterima pasien dewasa untuk pemeriksaan cervical AP $\mathrm{mGy}$ dan dosis median sebesar 0,99 mGy.

Selain itu diperoleh pula satu data adalah 0,57 mGy, dengan dosis tertinggi dosis pasien dewasa untuk pemeriksaan sebesar 0,87 mGy, dosis terendah 0,40 cervical oblique, clavicula AP dan thoracal $\mathrm{mGy}$ dan dosis median sebesar 0,45 mGy. lumbal, yaitu masing-masing sebesar 1,40

Gambar 12 memperlihatkan penerimaan dosis pasien dewasa untuk pemeriksaan mGy, 0,03 mGy dan 0,22 mGy. BAPETEN juga tidak memberikan nilai $\mathrm{DRL}$ untuk cervical lat. Gambar tersebut menunjukkan ketiga jenis pemeriksaan ini. Secara 
keseluruhan, Tabel 1 memberikan jumlah pasien dan nilai data dosis pasien dewasa keseluruhan yang terukur dalam penelitian ini.

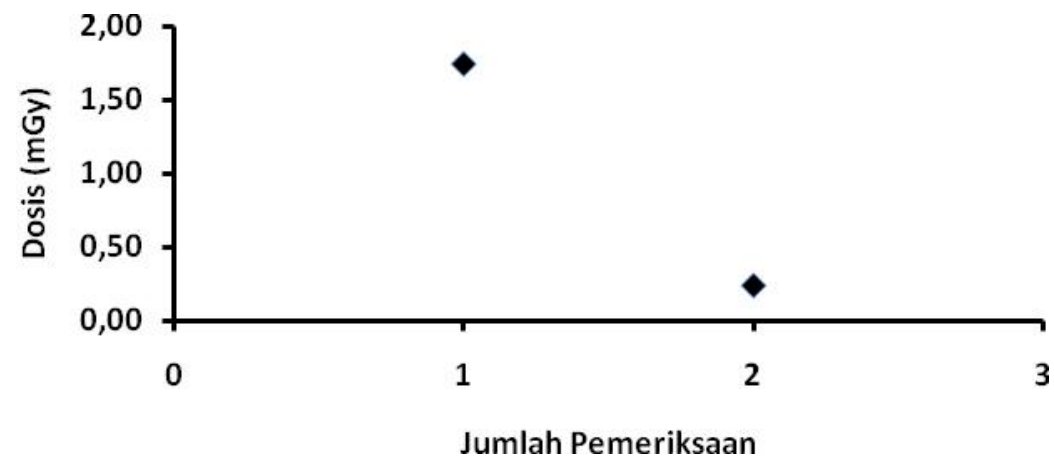

Gambar 12. Dosis radiasi yang diterima pasien dewasa pada pemeriksaan cervical Lat.

Tabel 1. Dosis permukaan masuk pada pasien dewasa untuk beberapa jenis pemeriksaan.

\begin{tabular}{|c|c|c|c|c|c|c|}
\hline \multirow[b]{2}{*}{ No. } & \multirow[b]{2}{*}{ Jenis pemeriksaan } & \multirow{2}{*}{$\begin{array}{l}\text { Jumlah pasien } \\
\quad \text { (orang) }\end{array}$} & \multicolumn{4}{|c|}{ Dosis permukaan masuk (mGy) } \\
\hline & & & Min & Maks & $\begin{array}{l}\text { Rata- } \\
\text { Rata }\end{array}$ & Median \\
\hline 1. & Thorax AP/PA & 26 & 0,07 & 2,37 & 0,39 & 0,23 \\
\hline 2. & Thorax Lat & 3 & 0,08 & 0,58 & 0,4 & 0,58 \\
\hline 3. & Abdomen & 11 & 0,80 & 3,57 & 1,74 & 1,47 \\
\hline 4. & Kepala AP/PA & 3 & 0,89 & 1,06 & 0,97 & 0,95 \\
\hline 5. & Kepala Lat & 2 & 0,28 & 1,00 & 0,64 & 0,64 \\
\hline 6. & Lumbosacral AP & 9 & 0,08 & 5,12 & 2,25 & 1,38 \\
\hline 7. & Lumbosacral Lat & 8 & 1,33 & 25,72 & 8,22 & 6,50 \\
\hline 8. & Ekstremitas & 30 & 0,04 & 1,94 & 0,39 & 0,14 \\
\hline 9. & Pelvis AP & 2 & 1,35 & 1,40 & 1,37 & 1,37 \\
\hline 10. & Cervical AP & 3 & 0,40 & 0,87 & 0,57 & 0,45 \\
\hline 11. & Cervical Lat & 2 & 0,24 & 1,75 & 0,99 & 0,99 \\
\hline 12. & Cervical oblique & 1 & - & - & 1,40 & 1,40 \\
\hline 13. & Clavicula & 1 & - & - & 0,03 & 0,03 \\
\hline 14. & Thoracal lumbal & 1 & - & - & 0,22 & 0,22 \\
\hline & Total pasien & 102 & & & & \\
\hline
\end{tabular}

Tabel 2 memperlihatkan perbandingan dosis permukaan masuk yang diterima oleh pasien dewasa pada penelitian ini dengan hasil studi IAEA (9), hasil studi dari beberapa negara maju yang dikutip IAEA (9), dan hasil studi di Malaysia (3). Seperti terlihat pada Tabel 2, kecuali untuk dosis pada pemeriksaan thoraks PA yang relatif sama, beberapa dosis pada pemeriksaan yang lain umumnya lebih rendah dari hasil yang diperoleh IAEA. Tabel 2 juga memperlihatkan bahwa dosis pasien di Indonesia dan Malaysia sebagai negara berkembang relatif tidak berbeda dengan dosis pasien di negara-negara maju tersebut, bahkan beberapa dosis jauh lebih kecil.

Tabel 3 memberikan data dosis permukaan masuk dari pemeriksaan thorax 
AP/PA, abdomen, kepala AP/PA, kepala lat anak-anak di bawah 16 tahun. dan ekstremitas untuk 28 orang pasien

Tabel 3. Dosis permukaan masuk pada pasien anak-anak usia hingga 16 tahun.

\begin{tabular}{|c|c|c|c|c|c|c|}
\hline \multirow[b]{2}{*}{ No. } & \multirow[b]{2}{*}{ Jenis pemeriksaan } & \multirow[b]{2}{*}{$\begin{array}{l}\text { Jumlah pasien } \\
\text { (orang) }\end{array}$} & \multicolumn{4}{|c|}{ Dosis permukaan masuk (mGy) } \\
\hline & & & Min & Maks & $\begin{array}{l}\text { Rata- } \\
\text { Rata }\end{array}$ & Median \\
\hline 1. & Thorax AP/PA & 2 & 0,05 & 0,63 & 0,19 & 0,14 \\
\hline 2. & Abdomen & 2 & 0,07 & 1,29 & 0,68 & 0,68 \\
\hline 3. & Kepala AP/PA & 2 & 0,24 & 0,58 & 0,41 & 0,41 \\
\hline 4. & Kepala Lat & 8 & 0,38 & 0,83 & 0,60 & 0,60 \\
\hline 5. & Ekstremitas & 14 & 0,04 & 0,39 & 0,18 & 0,16 \\
\hline & Total pasie & 28 & & & & \\
\hline
\end{tabular}

Tabel 4. Nilai dosis permukaan masuk untuk anak usia 10 tahun yang teramati di Eropa.

\begin{tabular}{lccc}
\hline \multirow{2}{*}{ Jenis pemeriksaan } & \multicolumn{3}{c}{ Dosis permukaan masuk (mGy) } \\
\cline { 2 - 4 } & Minimum & Maksimum & Median \\
\hline Thorax AP/PA & 0,02 & 1,16 & 0,07 \\
Thorax AP (mobile) & 0,03 & 0,76 & 0,09 \\
Thorax Lat & 0,04 & 1,98 & 0,15 \\
Kepala AP/PA & 0,13 & 5,21 & 1,04 \\
Kepala Lat & 0,11 & 3,79 & 0,58 \\
Pelvis AP & 0,09 & 4,17 & 0,81 \\
Thoracic spine PA/AP & 0,20 & 4,31 & 0,89 \\
Thoracic spine Lat & 0,30 & 6,66 & 1,63 \\
Lumbar spine AP & 0,13 & 5,69 & 1,15 \\
Lumbar spine Lat & 0,25 & 23,5 & 2,443 \\
Abdomen AP/PA & 0,15 & 3,98 & 0,73 \\
\hline
\end{tabular}

Dengan membandingkan Tabel 1 dengan Tabel 3, terlihat bahwa hasil pengukuran dosis pasien dewasa lebih besar dibanding dengan hasil pengukuran dosis pasien anakanak, yang berarti dosis yang diterima pasien anak-anak lebih kecil dari dosis yang diterima pasien dewasa. Hasil ini dapat di-pahami mengingat pasien dewasa yang me-miliki tubuh lebih tebal dibanding pasien anak-anak membutuhkan dosis radiasi yang lebih besar untuk dapat menembusnya dan menghasilkan citra organ sesuai dengan yang diinginkan.

Tabel 4 memberikan nilai dosis permukaan masuk untuk anak usia 10 tahun yang terukur di Eropa (15). Jika data dosis permukaan masuk pada Tabel 3 dibanding-kan dengan data pada Tabel 4, terdapat tiga jenis pemeriksaan yang sama, yaitu kepala AP/PA, kepala Lat dan thorax AP/PA. Untuk nilai median dari ketiga jenis pemeriksaan, dosis permukaan masuk pemeriksaan kepala Lat yang terukur baik di Eropa maupun di penelitian ini memberikan nilai yang sama, sementara pemeriksaan kepala AP/PA dan pemeriksaan thorax AP/PA memiliki perbedaan nilai hingga 60 dan $100 \%$.

Namun demikian, perbedaan nilai 
dosis terukur yang cukup besar pada kedua jenis pemeriksaan tidak berarti ada kesalahan pada salah satu pengukuran. Berbagai parameter mempengaruhi pengukuran nilai dosis permukaan masuk ini, antara lain tebal tubuh pasien dan parameter pesawat sinar- $X$ yang digunakan, seperti tegangan tabung $(\mathrm{k} \vee p)$ dan arus (mAs) (14).

Secara umum, dosis permukaan masuk pada pemeriksaan radiologi diag-nostik yang terukur pada penelitian ini masih di bawah nilai DRL yang berlaku di Indonesia. Dengan demikian, hasil peneliti-an ini juga memberikan indikasi bahwa pesawat sinar- $X$ yang digunakan juga cukup optimum dan mampu menghasilkan kualitas citra yang baik.

Penelitian yang sejenis dengan studi ini akan dilakukan untuk sampel pasien dan jenis pemeriksaan radiologi diagnostik yang lebih banyak yang diukur pada berbagai rumah sakit rujukan lain di Indonesia. Data yang terkumpul selanjutnya akan digunakan untuk menentukan DRL pada berbagai jenis pemeriksaan radiologi diagnostik yang dilakukan di Indonesia.Karena median merupakan nilai yang paling banyak teramati pada suatu kumpulan data, DRL akan dihitung dari nilai median tersebut yang merupakan nilai kuartil ketiga dari kumpulan data dosis permukaan masuk yang ada (2)

\section{KESIMPULAN}

Berdasarkan pembahasan di atas dapat disimpulkan bahwa secara umum dosis permukaan masuk pasien yang diperoleh pada studi ini menunjukkan nilai yang tidak melebihi nilai tingkat acuan diagnostik yang berlaku di Indonesia, dan sesuai dengan perkiraan, hasil studi juga menunjukkan bahwa dosis radiasi yang diterima pasien anak-anak lebih dan kecil di-banding yang diterima pasien dewasa. Per-bandingan nilai dosis pasien yang diperoleh pada studi ini dengan hasil yang diperoleh dari beberapa negara lain juga memperlihatkan bahwa dosis pasien di Indonesia dan Malaysia sebagai negara berkembang relatif tidak berbeda dengan dosis pasien di negara - negara maju.

\section{UCAPAN TERIMA KASIH}

Terima kasih diucapkan kepada para staf di RSUD Wahidin Sudirohusodo, Makassar, RSUD Syamsudin, SH, Sukabumi dan RS St. Antonius, Pontianak, yang telah membantu mengoperasikan pesawat sinar-X diagnostik, dan kepada Sdri. Dyah D. Kusumawati, Helfi Yuliati dan Suyati yang telah membantu melakukan pengukuran. Penelitian ini dapat terlaksana dengan dukungan dana dari DIPA PTKMR BATAN tahun 2014.

\section{DAFTAR PUSTAKA}

1. Gonzalez AJ. Current status on the global levels of radiation exposure. Proceedings of the International Conference on the Sources, Effects and Risks of lonizing Radiation; 2013 Oct 10-11; Jakarta:Center for Technology of Radiation Safety and Metrology; 2014. P. 16-54.

2. Hart D, Hillier MC, Shrimpton PC. Doses to patients from radiographic and fluoroscopic x-ray imaging procedures in the UK - 2010 Review, HPA-CRCE-034. Chilton: HPA; 2012.

3. Abdullah MHRO, Kandaiya S, Lim TH, 
Chumiran SH. Preliminary study on the trend of patient dose arising from diagnostic X-Ray examination in Penang, Malaysia. J.Appl.Sci.Res, 2010;6(12):2257-2263.

4. Osman H, Sulieman A, Suliman II, Sam, AK. Radiation dose measurements in routine X-ray examinations. Proceedings of the tenth Radiation Physics \& Protection Conference;Nov 27-30, 2010; Nasr City, Cairo, Egypt; 2010.

5. Compagnone G, Angelini P, Domenichelli S. Radiation doses to the population of the Emilia-Romagna region from medical exposures. Radiol.Med, Mar 2012;117(2);312-321.

6. Blanco S, Mora P, Almonte N, Benavente $\mathrm{T}$, Benson N, Blanco D, et.al. Determination of diagnostic reference levels in general radiograhy in Latin America. Radiat.Prot.Dosim. Sep 2013;156(3):303-309.

7. Ofori K, Gordon SW, Akrobortu E, Ampene AA, Darko E. Estimation of adult patient doses for selected X-ray diagnostic examinations. J.Radiat.Res.Appl.Sci. 2014;7(4):459-464.

8. Samara ET, Aroua A., Bochud FO, Ott B, Theiler $\mathrm{T}$, Treier R, et.al. Exposure of the Swiss population by medical x-rays: 2008 Review. Health Phys. March 2012;102(3):263-270.

9. Muhogora WE, Ahmed NA, Almosabihi A, Alsuwaidi JS, Beganovic A, Ciraj-Bjelac O, et.al. Patient doses in radiographic examinations in 12 Countries in Asia, Africa and Eastern Europe: Initial Results from IAEA Projects. Am.J.Roentgenol. 2008;190 (6):1453-1461.
10.Nuraeni N, Milvita D, Widora I, Kusumawati DD. Estimasi mean glandular dose (MGD) menggunakan metode Technical Reports Series (TRS) 457 pada pemeriksaan mammografi, Prosiding Seminar Nasional Keselamatan Kesehatan dan Lingkungan VII; 6-7 Juli 2011;Jakarta:PTKMR;2011. P. 21-28.

11. Yuliati $H$, Prasetio $H$, Suyati, Kusumawati DD, Nugraha ED. Estimasi terimaan dosis organ thymus dan tiroid pada pasien foto thorax secara perhitungan, Prosiding Pertemuan dan Presentasi IImiah Fungsional Pengembangan Teknologi Nuklir VII; 14 November 2012;Jakarta:PTKMR;2012. P.157-63.

12.Walker $C$, van der Putten. Patient dosimetry and a novel approach to establishing diagnostic reference levels in dental radiology. Phys. Med, 2012;28:7-12.

13. Vogiatzi, S, Kipouros P, Chobis M, Establishment of dose reference levels for nuclear medicine in Greece.

Radiat.Prot.Dosim. 2011; 147(1-2):237239.

14.Shahbazi-Gahrouei D, BaradaranGhahfarokhi M.Investigation of patient dose from common radiology examinations in Isfahan, Iran. Adv.Biomed Res. 2012;1:11. Available from:

http://www.ncbi.nlm.nih.gov/pmc/article s/PMC3507008/

15. International Commission on Radiological Protection. Radiological protection in paediatric diagnostic and 
Jurnal Sains dan Teknologi Nuklir Indonesia

Indonesian Journal of Nuclear Science and Technology

Vol. 16, No 2, Agustus 2015; 71-84

ISSN 1411 - 3481

interventional radiology, ICRP Publication

121.2013;Ann. ICRP 42(2):26. 